\title{
Dividend Policy for Commercial Banks in Tanzania: Controlling for Random and Specific Effects
}

\author{
Richard F. Kiangi ${ }^{1 *}$ Mesiet William ${ }^{1}$ Rufina J. Milamo ${ }^{2}$ \\ 1.The Institute of Finance Management, PO Box 3918, 5 Shaaban Robert Street. 11101 Dar-es-Salaam, Tanzania \\ 2.Institute of Tax Administration, PO Box 9321, Mikocheni "B" Light Industrial Area. Dar-es-Salaam, Tanzania \\ * E-mail of the corresponding author: rkiangi@gmail.com
}

\begin{abstract}
The study examines the determining factors of dividend policy of the regulated Tanzania's commercial banks, covering throughout 2009 to 2018. The variables under the study include dividend policy, firm size, liquidity, profitability and leverage. Data were collected from the audited financial statements, yearly reports, and proceedings from Annual General Meetings of the regulated commercial banks. The study examines Six (6) commercial banks in Tanzania. For inferential analysis, fixed and random effect panel data methods were employed. An ideal model was determined by using Hausman Test. Results revealed that while liquidity takes a negative yet minor effect in dividend pay-out of commercial banks in Tanzania, profitability and leverage revealed a positive and significant effect on the dividend pay-out. Furthermore, firm size determines dividend pay-out ratio since investors perceive big banks making profits are having greater chance to pay high dividends compared to small firms. This makes people invest in the banks expecting higher dividend yields in the future. The study findings will help the directors and management teams of banking sector to arrive at appropriate dividend policy. Moreover, the findings are useful to guide investors decisions. This research paper contributes to the commercial banks dividend policy body of knowledge. It also covers the gap in the prevailing literatures by concentrating on the issue of commercial banks in emerging markets specifically Tanzania.
\end{abstract}

Keywords: Dividend policy, Tanzania, Emerging market, Commercial banks, Determinants

DOI: $10.7176 /$ RJFA/13-4-02

Publication date: February $28^{\text {th }} 2022$

\section{Introduction}

There is a bunch of literatures that recognises the importance of dividends policy in corporate finance and its implications to company's stakeholders (investors, managers, lenders). The policy has multiple implications in financing, and investing decisions over and above a firm's capital structure. A firm's decision not to give dividend or pay a low dividend generates more internal earnings that are essential for further investment and decrease reliance on external borrowings. Contrary, a decision to pays a high dividend, reduces internal earnings and increase dependence on external financing. The dividend policy decision assists the firm's management to structure its dividend pay-out to shareholders and re-investment decision(Pattiruhu \& PAAIS, 2020). Firms face strategic decision challenge to balance between amount to pay as dividend and retain for investment (Inyiama et al., 2015).

The discussion on relevance of dividend policy has been a continuous headline among the researchers since the works of Gordon and Shapiro (1959), Lintner (1956) also reviewed in (1962), and Miller and Modigliani (1961) who are famously referred as pioneers of the dividend policy subject. The general dividend policy's philosophy is still indescribable, in the same manner, dividend practices differs overtime among different companies and countries. (Attah-Botchwey, 2014; Pattiruhu \& PAAIS, 2020). For decades, researchers have empirically studied the determinant of dividend policy. In spite of the plenty researches on the subject, the findings conveyed remain indecisive. Besides, prior researches indicate that great percentage of the past empirical research efforts on dividend pay-out were stressed on industrialized capital market countries. Sub-Saharan Africa countries (SSA) and emerging markets have received little attention on this important topic that is attracting a large number of researchers today. There is little attention and therefore inadequate studies on companies' dividend pay-out in developing countries and emerging markets focusing on commercial banks (Agyei \& Marfo-Yiadom, 2011; Ahmad et al., 2019; Amollo, 2016; Masum, 2014; Namachanja, 2016). Moreover, the number of studies cover diversity of companies from different sectors listed in stock exchange markets (Al-Najjar \& Kilincarslan, 2018; Alzomaia \& Al-Khadhiri, 2013; Yusof \& Ismail, 2016).

Currently, the economy of Tanzania is growing at a rate of 5 percent, which places it in the second position in East Africa. In July 2020 the World Bank upgraded Tanzania from low income to lower-middle-income level (WorldBank, 2021). Tanzanian Commercial sector is among the sectors that is actively growing and is expected to contribute about $48 \%$ of the GDP by 2025 (URT, 2016). Financial sector growth is expected to translate toward millennium development goals and the Tanzania vision 2025 that specifically aims at economic growth rate of $8 \%$ per annum, reduce income poverty, increase quality of livelihood, and attain strong competitive economy, in the regional and world market. Commercial sector specifically commercial banks are driving force for the realization 
of a vision by building the culture of saving and investment among Tanzanians; women empowerment by giving them soft loans and low-interest rates loans to entrepreneurs as well as educations loans (URT, 2016).

Maintainance of proper liquidity level is essential for commercial banks to supports development vision initiatives. Therefore, government policymakers, citizens, and researchers' eyes are on the banking industry, which not only play important role in poverty alleviation but also highly contributes to the country's economic growth. Currently, the banking sector contributes about $27 \%$ of the GDP (Bank of Tanzania, 2019). Recent upgrade of Tanzania economy to a lower-middle- income have heightened the need for financial sector growth, thus what determines dividend policy for commercial banks is crucial in positioning banks' capital structure, and cost of capital and investment decisions.

Specifically, this paper has the main of examining the determining factors of dividend policy for commercial banks in Tanzania. Apart from covering the existing gap, the paper significantly contributes in the existing body of literature by providing evidence from a country with emerging markets. This study extends from the previous study conducted by (Gwahula \& Mnyavanu, 2018), by using panel data from 2009 to 2018 . However, it deviates from Raphael and Mnyavanu, (2018) by employing a pooled ordinary least square model with fixed and random effects to control for the unobservable and firms specific effect error.

\section{Literature Review}

The dividend policy explains the context within which dividends can be managed outlining the details on decision for payment of dividend, the frequency of payment, types as well as modes of payment or combinations (Pandy, 2001). Quite a lot of theories have already developed in efforts of explaining the concept of dividend pay-out, firm's value and aspects determining dividend policy. Lintner model is one of the earliest studies model to unveil that prevailing profitability and the lagged dividends are crucial aspects in explaining variations in the current dividend of the firm (Lintner, 1956). Similarly, the study on connection between major USA firms' investment financing and dividend decisions highlighted that, firm's dividend decisions are enhanced by profit levels and the former year's dividend rather than financing actions and investment (Pruitt \& Gitman, 1991).

Likewise, Irrelevance theory proved that the firms' value is invariant to its dividend policy, argued that a company dividend policy is merely a financing decision that has no effect of the value of the firm. The firm's value is determined exclusively by firm's investment portfolio rather than the manner of its financing arrangement (Miller \& Modigliani, 1961). The proposition is centered on the assumptions that, investment decisions are independent of a dividend policy and that borrowing policy is fixed.

Contrary, the bird-in-hand theory emphasis the significance of dividends to the firm's value(Gordon, 1962). This argument is constructed on the dividend claims that dividend received today are more certain than dividend that is retained or reinvesting in future projects whose actual earnings are non-certain, in addition shareholders prefer cash dividend rather than future capital gains due to lower risk from immediate cash (Baker \& Powell, 2000). The theory argues that a connection or significant relationship exists between dividend payment and firm's value since dividends represent a sure thing for owners as compared to capital (Gordon \& Shapiro, 1956; Salin \& Rahman, 2010).

The Signaling Theory also known as "information content of dividends" entails that firm's managers tend to use dividends for "signaling" asymmetric information on the firm's future earnings (Daniels et al., 1997). Investors can deduce information on forthcoming earnings of the firm by using the signal from declarations of dividends, in terms of both variations in dividends and the stability. Furthermore, it claims that the firm's shareholders may interpret the increase in dividend payment as a indication of firm's future profitability; therefore, the share price will rise in a positive reaction and vice versa (Miller \& Modigliani, 1961). Similarly, dividend payment announcement is interpreted as the stability (liquidity) of future a future cash flows of the firm (Charitou, 1999). Investigating the influence of cash flows on dividend payments of firms revealed a positive relationship between dividend change and earning measures (companies with profits will face dividend increase) as well as a positive significant association between the dividend payment and level of cash flow (Al Shabibi \& Ramesh, 2011; Anil \& Kapoor, 2008; Baskin \& Miranti Jr, 1997; Hashemi \& Kashani, 2012). In contrast, few research claimed a negative significant impact of earnings on dividend pay-out (Gill et al., 2010; Sim, 2011).

While Shareholders own the firm, managers control the firms' affairs, and regularly, there are differences between the interests of these two groups. Managers are after maximum reimbursement for their services whereas shareholders look for increased returns on their investments. The scenario is explained by the "Agency Theory" which underlines ways of mitigating costs that resulted from principal-agent problems. The theory advocates that paying dividend to shareholders is a fair mechanism of reducing the principal-agency conflict within a company for two (2) reasons. Firstly, dividends payments minimize the amount of free cash-flow that might have otherwise used on investments by the managers for their own benefits at the of shareholders' expenses (Jensen \& Meckling, 1976; Rozeff, 1982; Utami \& Inanga, 2011). Secondly, payment of dividends exposes a company to more frequent examinations and check-up by the stock market since dividend payment upsurge the possibility of new common stocks issue (Easterbrook, 1984). 
Empirically, a numeral of researches have highlighted the determinants of dividend pay-out and the relationship that exist among them. Studies indicates significant effect of companies' profitability and the previous dividend rate on the decision of the company of increasing or decreasing dividends' level. (Al Shabibi \& Ramesh, 2011; Alzomaia \& Al-Khadhiri, 2013; Awad, 2015; Banerjee et al., 2002; Imran, 2011). A positive relationship illustrates that companies are more willing to pay high dividends when profitability increases with reflection of the high level of dividends of last year. A company's growth was observed to have a non-significant negative effect. (Alzomaia \& Al-Khadhiri, 2013), signifying that companies that experience growth opportunities have high probability of cutting out dividends. Analysis of firm's specific factors indicate that, matured and bigger sized companies are highly likely to pay higher dividends (Awad, 2015; Huda \& Farah, 2011; Ramli, 2010; Yusof \& Ismail, 2016). However, Pattiruhu and PAAIS, (2020) and Sim, (2011) found no influence of current ratio on company's dividend policy. While firms with more debts have low probability of paying dividends (Al - Malkawi, 2007; Awad, 2015; Pattiruhu \& PAAIS, 2020).

Similarly, the study conducted in MENA (emerging markets) concluded that dividend pay-out has positive relationship with firm's size, liquidity and present profits and at the same time, having a negative association with leverage, growth, free-cashflow and the state's economy (Jabbouri, 2016). Public listed companies in Malaysia indicated firm's size and investment have a positive significant consequence, whereas debt and huge shareholders have a negative but, significant effect with dividend policy (Yusof \& Ismail, 2016). A study performed for companies listed in Dar-Es-Salaam stock exchange revealed profit margin, expected upcoming earnings, dividend growth, future investment opportunities, and earnings stability are key drivers of dividend policy supporting the dividend relevance theory (Ngole, 2015).

On the other hand, audit type, growth opportunities, liquidity as well as profitability are the main determining factors of dividend pay-out of pharmaceutical firms in Pakistan Stock Exchange (Khan and Ahmad, 2017), and in Ghana (Nuhu, 2014) while, firm size, risk, taxation and leverage had insignificant impact on dividend pay-out decisions (Khan and Ahmad, 2017) . Highly geared firms also require higher liquidity to allow for payments of expected claims to maintain liquidity, such firms might lower dividend pay-outs hence require less outside financing, provided that they are retaining internal cash for strengthening liquidity (Baker et al., 2002). Thus, an inverse relationship exists between liquidity and dividend policy because more cash paid-out to investors in forms of dividends is likely to reduce the firm's cash in hand. On the other hand, profitability, and ownership structure and past dividends were positively related with dividend pay-out while liquidity was negatively related to dividend pay-out of the banking sector of international and local banks listed at different stock exchanges of Pakistan (Zameer et al., 2013). differently, Gwahula and Mnyavanu, (2018) analysed the determinant of dividend pay-out for Tanzania's commercial banks. The study employed panel data spanned from 2010 to 2016 . With the use of classical linear regression method, the study found a significant and positive influence of profitability and liquidity; leverage and bank growth indicated significance with inverse impact on dividend policy, while bank size was found to have no any impact on the dividend pay-out (Gwahula and Mnyavanu, 2018).

\section{Methodology}

\subsection{Sampling, Data Collection and Variables}

The present study uses purposive sampling method to select listed firms by using the following criteria: Selected banks should be having regular annual financial statements for the whole period of the study, and it should be in operation for about five years or more. Furthermore, it should have Positive earnings. Six commercial banks (NMB bank, CRDB Bank, Exim Bank Tanzania, DCB Commercial Bank, Standard Chartered Bank Tanzania, and I\&M Bank Tanzania) out of 38 regulated by Bank of Tanzania were chosen.

The main sources of data used in the study were the sampled companies audited financial statements from 2009 to 2018. Furthermore, the data were collected from companies' annual reports and proceedings from Annual General Meetings (AGMs) of the companies. Dividend Pay-out $\left(\mathrm{DPO}_{\mathrm{t}}\right)$ serves as the dependent variable while Profitability $\left(\mathrm{PRT}_{\mathrm{t}}\right)$, Firm Size $\left(\mathrm{FS}_{\mathrm{t}}\right)$, Liquidity $\left(\mathrm{LIQ}_{\mathrm{t}}\right)$, and Financial Leverage $\left(\mathrm{LEV}_{\mathrm{t}}\right)$ are the control variables.

Table 1: Summary of the Variables and Proxies

\begin{tabular}{llll}
\hline Sn & Variable & Represented by & Proxies \\
\hline & & & \\
1 & Dividend Policy & DPO & Dividend Pay-out Ratio = dividend/ Net Income \\
2 & Leverage ratio & LEV & Total debt/Total asset \\
3 & Liquidity & LIQ & Current assets/ Currents liability \\
4 & Firm Size & FS & The natural logarithm of Total Assets \\
5 & Profitability & PRT & Net profit/ Sales \\
\hline
\end{tabular}

Source: Author's construction from literature review 


\subsection{Data Analysis and Model Specification}

The study used random effect model to examine determinants of dividend pay-out among the regulated Tanzania's commercial banks. As indicated earlier, the panel data (PD) estimation methods were well-thought-out the most efficient analytical techniques, as they allow combination of various cross-sections and periods, as well as providing more reliable, valid and vigorous inferences. Precisely, Panel Data unambiguously considers individualspecific heterogeneity! Similarly, by merging data into two dimensions, Panel Data provides less co-linearity, more variations in data, and higher degree of freedom.

The Fixed Effects (FE) technique undertakes that individually group, that is, banks, has a non-stochastic group-specific element to the dividend policy, the controlled variable. This is to say that, Fixed Effect undertakes that an individual-specific effect is associated with the dependent variable (dividend policy) whereas Random Effect (RE) assumes that individual-specific effects are not correlated with the control variables. Fixed effect method is shown as follows:

$$
Y_{i t}=\alpha_{i}+\beta \cdot X_{i t}+u_{i t}
$$

Where:

$\alpha_{i}$ is a bank fixed effect, these are specific intercepts (fixed for a given $\mathrm{N}$ ). No general intercept is encompassed

in the model. $u_{i t}$ is a normal random error term. In fixed effect, consistency does not entail, that the specific intercepts (with $\alpha_{i}{ }^{\prime} s$ coefficients) and the disturbance term $\left(u_{i t}\right)$ are uncorrelated. Only

$E\left(X_{i t} u_{i t}\right)$ should hold and the variables are expressed as;

$$
\begin{aligned}
& Y_{i t}=\quad \text { Dependent variable value (Dividend Pay-out) for } i^{\text {th }} \text { bank at } t^{\text {th }} \text { time period } \\
& X_{i t}=\quad \begin{array}{l}
\text { The value of independent variables, Leverage ratio (LEV), liquidity (LIQ), Firm Size (FS), } \\
\text { and Profitability (PRT) for the } i^{\text {th }} \text { bank-in } t^{\text {th }} \text { period of time. }
\end{array}
\end{aligned}
$$

When dummy variables are included in the Fixed Effect, it acts as a means of regulatory unobservable effects on dividend policy, controlled variable. Nevertheless, such unobservable effects can be random (stochastic). The random effects (RE) technique thus, tends to solve this problem. The Random Effect model specification is specified as;

$$
\begin{gathered}
Y_{i t}=\alpha+\beta . X_{i t}+v_{i}+u_{i t} \\
\text { Where } \quad v_{i} \sim \operatorname{iid}\left(0, \sigma_{\alpha}^{2}\right) \\
u_{i t} \sim \operatorname{iid}\left(0, \sigma_{\alpha}^{2}\right)
\end{gathered}
$$

Where $v_{i}$ is the non-observed bank-specific effects (the random effect) and $v_{i} s$ are ran-dom variables that have the equal variance. $v_{i}$ is explicit for an specific bank. The $v$ of discrete banks are independent, with a zero mean, and their distribution is presumed to be not too far from normality. An inclusive mean is apprehended in $\alpha$. $v_{i}$ is homoscedastic across specific banks and non-time variant. The test statistics (t-test) is applied to test the significance of coefficients of individually variable used in the model, whereas the $F$-test is used for testing if the coefficients are mutually or simultaneously equivalent to or different from zero $(0)$.

When there is an unobserved specific effect, it is presumed that there is a distinct/individual firmspecific error-term $\left(\alpha_{i}\right)$ and an idiosyncratic error-term $\left(\varepsilon_{i \mathrm{it}}\right)$ that is non-correlated with either $X_{i t}$ or error $\left(\mu_{i t}\right)$ is equal to $\alpha_{i}+\dot{\varepsilon}_{\text {it }}$. Linear model therefore becomes:

$Y_{i t}=\alpha_{i}+\beta . X_{i t}+u_{i t}$

If $\alpha_{i}$ is correlated to $X_{i t}$ denoting that $\mu_{i t}$ is allied to $X_{i t}$ ( since $\mu_{i t}=\alpha_{i}+\varepsilon_{\text {it }}$ ), then the Fixed Effect model would give reliable estimators however OLS estimators would be unreliable. Again, if $\alpha_{i}$ is not correlated to $X_{i t}$, OLS estimators could be consistent yet, not efficient since $\mu_{i t}$ is serially and heteroskedastic auto correlated (provided that an error term varies from firm to firm, then does not have constant variance). To upsurge the efficiency, the Random Effect model is chosen. The justification for the Random Effect method is that, different from the fixed effect model, the disparity across the banking industries is presumed to be random and non-correlated with independent variables or predictor included in the models crossways all time periods. By assuming that banking industry-specific error term is un-correlated with the explanatory (independent) variables, the Random Effect model permits for time-invariant variables to act as control 
variables. A multiple regression method was used to test the relationship between determinants of dividend policy on regulated commercial banks in Tanzania.

$\mathrm{Y}_{\mathrm{it}}=\beta_{0}+\beta_{1}(\mathrm{LEV})_{\mathrm{it}}+\beta_{2}(\mathrm{LIQ})_{\mathrm{it}}+\beta_{3}(\mathrm{FS})_{\mathrm{it}}+\beta_{4}(\mathrm{PRT})_{\mathrm{it}}+\dot{\varepsilon}_{\mathrm{it}}$

Whereas;

$Y_{i, \mathrm{t}}=$ Dividend Pay-out for bank $i$ in year $\mathrm{t}$

$\beta_{0}=$ Constant coefficient

$\beta_{1}(\mathrm{LEV})_{i, \mathrm{t}}=$ Leverage ratio

$\beta_{2}(\mathrm{LIQ})_{i, t}=$ Liquidity ratio

$\beta_{3}(\mathrm{FS})_{i, t}=$ Firm Size

$\beta_{4}(\mathrm{PRT})_{i, t}=$ Profitability

$\epsilon_{i, t}=$ an idiosyncratic disturbance term (Error term)

\subsection{Hausman Test}

The Hausman test, put forward by Hausman, (1978) was employed to determine if the data fit well fixed effect or the random effect method, under the Null Hypothesis $\left(\mathrm{H}_{0}\right)$ that the Random Effect estimators are competent and consistent, and Fixed Effect estimators are incompetent. Hausman Test has a Wald test form that usually conveyed in $\chi^{2}$ form, with $k-1$ degrees of freedom. $\mathrm{k}$ being the number of repressors. Particularly, the Null Hypothesis $\left(\mathrm{H}_{0}\right)$ and Alternative Hypothesis $\left(\mathrm{H}_{1}\right)$ of the Hausman test are stated in the following expression;

$\mathrm{H}_{0}$ : All non-observed factors (random-component and Random-effects model is appropriate deterministic components) that differ across components (units) but are constant over-time, are uncorrelated to the control variables.

$\mathrm{H}_{1}$ : $\quad$ Non-observed factors (the deterministic element and Fixed effects model is appropriate random factor) that differ crossways units but are invariant over time are associated with the control variables.

If the probability value (Prob. Chi-square) is larger than 5

We apply a RE model percent $(0.05)$, this is to say that, if $\mathrm{W}<$ critical value then random effects is the preferred estimator.

If probability value is less than or equal to 0.05 (Prob. Chi-square $<0.05)$, then fixed effect is an ideal model

\section{Empirical Results and Discussion of the Findings \\ 4.1 Descriptive Statistics Results}

From table 2, mean value of dividend pay-out measured in Dividend to Net Income is 0.5983 indicating that the commercial banks operating in Tanzania distribute $59.8 \%$ of their profits to their shareholders with $26.1 \%$ variation as a risk in their return. In this regard, this therefore means that $40.2 \%$ of their earnings are retained for future reinvestments. This is attractive to the investors since it is above the average value, that is $27 \%$. Results, shows that profitability measured by net profit to sales is 0.2092 , indicating that the banks generated an average of 0.2092 , which is $20.9 \%$ net profit from sales. Generally, commercial banks in Tanzania need to improve the strategies used to generate and increase sales of their products, which will not only increase profitability, but also increase the chances of dividend pay-out. In profitability generating, Tanzania commercial banks had 0.1937 unpredictability for the period from the year 2009 to 2018 which is a sign of low risks of $19.3 \%$ on producing profit from sales. Liquidity measured by current asset to current liability had a mean value of 0.4084 equally to the $40.84 \%$ liquidity position, with the dispersal of $14.50 \%$ ups and downs.

The character of the banking industry is extremely dependent on deposits, which are debts, for financing their operations. However, by having a liquidity mean value of $40.84 \%$, Tanzania commercial banks have maintained a liquidity requirement of Bank of Tanzania (BOT) which is $15 \%$ minimum. Furthermore, firm size measured by total assets had a mean value of 0.8136 equal to $81.36 \%$ in their composition mainly from their total assets. Obviously, this signifies that Tanzania commercial banks contain higher total asset and therefore, their higher size. The standard deviation of the firm size was $6.69 \%$ variability, which is still low (less than $10 \%$ ), implying a low risk attached to their assets generation and maintaining. A maximum of this variable was $73.21 \%$ and it shows that all commercial banks maintain the requirement set by the BOT. 
Table 2: Descriptive Statistics Results

\begin{tabular}{|c|c|c|c|c|c|}
\hline & DVP & PRT & LEV & LQ & FS \\
\hline Mean & 0.5983 & 0.2092 & 0.8312 & 0.4084 & 0.4365 \\
\hline Median & 0.5609 & 0.1240 & 0.8501 & 0.4360 & 0.4294 \\
\hline Maximum & 0.9059 & 0.6831 & 0.9201 & 0.8808 & 0.7321 \\
\hline Minimum & 0.3191 & 0.0517 & 0.6691 & 0.1529 & 0.1299 \\
\hline Standard Dev. & 0.2612 & 0.1937 & 0.0680 & 0.1450 & 0.1420 \\
\hline \hline Observations & $\mathbf{6 0}$ & $\mathbf{6 0}$ & $\mathbf{6 0}$ & $\mathbf{6 0}$ & $\mathbf{6 0}$ \\
\hline
\end{tabular}

Source: E-view-9 computation output

\subsection{Correlation Analysis}

Table 3 reports that profitability (PRT) of Tanzanian commercial banks is negatively correlated with dividend payout. That is, as the profitability increases, dividend pay-out moves in the opposite direction. This implies that Tanzanian commercial banks are on the growing stage and most of their profits are used for investment rather than distribution to shareholders. On the other hand, liquidity and dividend pay-out ratio are positively correlated, meaning that when liquidity increases dividend pay-out also increases. Leverage and dividend pay-out of commercial banks in Tanzania are also positively correlated. The dividend pay-out ratio is positively correlated with the banks' size and the previous year's dividend, implying that as banks size increases dividend pay-out also increases.

Table 3: Correlation Matrixes of Dependent and Independent Variables

\begin{tabular}{l|ccccc}
\hline & DVP & PRT & LQ & LEV & FS \\
\hline DVP & $\mathbf{1 . 0 0 0 0}$ & & & & \\
\hline PRT & -0.0807 & $\mathbf{1 . 0 0 0 0}$ & & & \\
\hline LQ & 0.0809 & -0.0775 & $\mathbf{1 . 0 0 0 0}$ & & \\
\hline LEV & 0.1405 & -0.3811 & -0.2630 & $\mathbf{1 . 0 0 0 0}$ & \\
\hline FS & 0.3752 & 0.3994 & -0.1368 & 0.1150 & $\mathbf{1 . 0 0 0 0}$ \\
\hline
\end{tabular}

Source: E-view-9 output

\subsection{Panel Unit Root Test}

The stationary conditions for time series data were examined by means of tests established by Levin, Lin, and Chu (2002) and Pesaran and Shin (2003) from the first-generation unit root test. The results of the test, reported on Table 4 specifies existence of unit root at level except for firm size. This implies that most of the series are not stationary at level, hence the series were subject to the first differences test. After running for the first difference all variables were observed to be stationary. Stressing on the unit root test results (Im et al., 2003; Levin et al., 2002), the study has two panel regression models (that is Random and Fixed effect) for determining the relationship among the variables under the study. The Hausman Test was employed to identify a suitable regression model for the study

Table 4. Panel Unit Root Test Results.

\begin{tabular}{|l|l|l|l|l|}
\hline \multicolumn{2}{|c|}{ LLC } & \multicolumn{2}{c|}{ IPS } \\
\hline Variables & Stable & Stable and Trend & Stable & Stable and Trend \\
\hline PRT & $-1.3044(0.0961)$ & $-0.54680(0.2923)$ & $-2.4223(0.0077)$ & $-2.11902(0.0170)$ \\
\hline LEV & $2.17508(0.9852)$ & $0.37087(0.6446)$ & $2.61396(0.9955)$ & $1.57978(0.9429)$ \\
\hline LIQ & $-0.95450(0.1699)$ & $0.46911(0.6805)$ & $-2.42768(0.0076)$ & $-1.40899(0.0794)$ \\
\hline FS & $-8.93007(0.0000)$ & $-7.31870(0.0000)$ & $-7.69899(0.0000)$ & $-5.60504(0.0000)$ \\
\hline First Differences & $-7.45187(0.0000)$ & $-5.37690(0.0000)$ & $-8.94763(0.0000)$ & $-6.86894(0.0000)$ \\
\hline PRT & $-3.78790(0.0001)$ & $-2.08413(0.0186)$ & $-5.68284(0.0000)$ & $-4.38714(0.0000)$ \\
\hline LEV & $-7.02766(0.0000)$ & $-5.08741(0.0000)$ & $-8.17814(0.0000)$ & $-6.14818(0.0000)$ \\
\hline LIQ & $-12.7541(0.0000)$ & $-11.1085(0.0000)$ & $-12.9539(0.0000)$ & $-10.9816(0.0000)$ \\
\hline FS
\end{tabular}

The numbers in brackets show p-values. In the LLC test, the Newey-West band width was selected and estimation was executed on conferring to Barlett kernel technique. The maximum number of delays was automatically selected and the maximum delay length was determined using Schwarz information criterion. 


\subsection{Hausman Test Results}

The Null Hypothesis of the test was that, random effect model is the suitable or preferred model regression model. Table 5 indicate that the p-value for the test is 0.000 (less than the Hausman Chi square), therefore, the Null Hypothesis was rejected. Following the Hausman test, the fixed effect method was chosen as a suitable model for the study.

Table 5: The Hausman Test Result

\begin{tabular}{llll}
\hline Effects Test & Statistic & d.f. & Prob. \\
\hline Cross-section Chi-square & 32.97705 & 5 & 0.0000 \\
\hline
\end{tabular}

Source: E-view-9 computation output

\subsection{Fixed Effect Model}

The fixed effect model results shown on Table 6 indicates that the adjusted $\mathrm{r}^{2}$ was 0.7211 . This entails that $72.11 \%$ of the dividend pay-out of Tanzania commercial banks was explained by PRT, LEV, LIQ, and FS. The rest $27.89 \%$ variation of dividend pay-out were explained by neither bank-individual/specific nor macroeconomic variables used in this study, instead is defined by the error term. Basically, the overall test of significant, that is F-statistics indicates that the model was good enough, fitted and statistical significant at 1 percent level (that is, $p$-value is equal to 0.000 ).

The coefficients of the regression equation are then given by:

\section{DVP $=0.2376+0.4737$ LEV -0.1692 LIQ + 0.7492FS + 0.2934PRT}

The study revealed that coefficients of the control or independent variables PRT, LEV, and FS had a significant and positive impact on dividend pay-out. Nevertheless, liquidity (LIQ) has a negative insignificant impact on dividend pay-out. Increasing a shilling in liquidity, keeping the other factors constant, results in a - 0.1692 decrease in dividend pay-out. These findings are conflicting Jensen's (1986) agency theory which states; firms that have a huge free cash flow tend to have higher dividend pay-out ratios (Jensen, 1986). The results are also contrary to the findings by Gwahula and Mnyavanu (2018), other studies support the results (Mitiku, 2015; Zameer et al., 2013).

Differently, profitability measured by net profit over sales showed a positive statistically significant influence on commercial banks' dividends pay-out. When profitability increases by one shilling, keeping the other factor unchanged, increases dividend pay-out by 0.1448 Shilling. This movement in the same direction implies that Tanzania commercial banks are more likely to pay dividends to their shareholders when they are profitable unlike when they are not. This result concurs the Agency Theory which argue that, the more profitable banks are, the higher the possibility for paying dividends, and vice-versa. It also confirms the claim of Linter (1956) that dividend payment is relevant since, as a firms pay-out dividend their firm's value increase. This indicates that Tanzania commercial banks believe that payments of dividend are crucial and significant to increase their value (firms value). This results various researchers (Awad, 2015; Banerjee et al., 2002; Dada et al., 2015; Gwahula \& Mnyavanu, 2018; Jabbouri, 2016; Mehta, 2012)

Table 6 reports a positive statistically significant leverage level on dividend pay-out for commercial banks in Tanzania. A unit increase in leverage, keeping the other things unchanged, results in 0.47366 units changes on dividend pay-out on a same direction. The result is against the theory of Bird in Hand Theory that outside financing has high financing and transaction cost as in comparison to un-levered companies. This results into decreases in their profit, subsequentially leading to a decreased proportion of dividend pay-out. It signifies that, Tanzania commercial banks are highly levered firms by the nature, since they extend loans to borrowers largely from the deposits collected from the public. The increased deposits lead to an increase in credit to be granted to borrowers and results to an increased profit, and likewise the amount of dividends to be extended to shareholders. These findings are in line with the prior empirical researches of Zameer et al (2013), Awad (2015) and contradict the findings of the following studies by Nuhu (2014), Jabbouri (2016), Gwahula and Mnyavanu, (2018) urged a negative influence of leverage on dividend policy. Contrary to Pattiruhu and PAAIS (2020) who observed insignificance but positive influence of firm size. The findings of this study report a positive and statistically significant relationship between firm size and dividend policy. An increase in a percentage of firm size increases chances of paying dividends $74 \%$ times. The evidence is supported by the findings of (Denis \& Osobov, 2008; Maladjian \& Khoury, 2014; Ngole, 2015; Yusof \& Ismail, 2016). 
Table 6: The Fixed Effect (FE) Model Regression

\begin{tabular}{|l|l|l|c|}
\hline Variables & Coefficient & \multicolumn{1}{|c|}{ t-Statistic } & Prob. \\
\hline C & 0.2376 & 1.6956 & 0.0940 \\
\hline PRT & 0.2934 & 4.1180 & $0.0456^{* * *}$ \\
\hline LEV & 0.4737 & 3.1093 & $0.0035^{* * *}$ \\
\hline LIQ & -0.1692 & -0.2437 & 0.1981 \\
\hline FS & 0.7492 & -1.2164 & $0.041^{* * *}$ \\
\hline R Square $=\mathbf{0 . 7 6 1 9}$ & Adjusted $\mathbf{R}^{\mathbf{2}}=\mathbf{0 . 7 2 1 1}$ \\
\hline F-statistic $=\mathbf{1 8 . 7 0 4 6}$ & Prob (F-statistic) $=\mathbf{0 . 0 0 0 0}$ \\
\hline
\end{tabular}

*** indicates significance 5\% level

Source: E-view 9 output

\section{Conclusion}

This paper examines the factors which affect the dividend policy of commercial banks listed companies in DSE. A total of six (6) commercial banks regulated by the Bank of Tanzania (BOT) have been used, namely; (CRDB Bank plc, National Microfinance Bank, Exim Bank Tanzania, DCB Commercial Bank, Standard Chartered Bank Tanzania, and I\&M Bank Tanzania) operating in Tanzania. The paper concluded that leverage, profitability, and firm size have a positive significant impact on dividend policy. Contrary, liquidity was observed to have a negative insignificant impact on dividend pay-out. In fact, the findings reveal that firms that have high profitability are larger, and have a high percentage of shares owned by big shareholders (since investors perceive big banks making profits highly likely to pay more dividends). They invest in the banks since they expect low debts, higher dividend yields, higher investment opportunities, and higher dividends in future.

The study offers useful inputs to the management and banks board of directors for dividend policy formulation and revision and when making decisions on dividend payment decision for their banks by giving considerable attention to profitability, firm size and leverage because they have a positive statistically significant influence on dividend pay-out contrary to liquidity that has negative statistically significant impact on dividend payment. This is crucial, as the dividend pay-out is an important feature for attracting new investors and retaining the existing investors. Besides, since higher dividend payments attract investors, it is vital for the management team to endeavor for more earnings, bigger firm size, lower debt levels and greater investment opportunities so as to satisfy the shareholders' wealth maximization goal in a form of more/high dividends. Since dividend payments are in a form of returns or rewards to shareholders, the findings of this study, similarly offer understandings to the potential and existing shareholders in relation to investment decisions making.

Since profit, firm size and leverage, have a positive and statistically significant effect on dividend paid-out and only liquidity has a negative and insignificant statistical impact on dividend paid by commercial banks in Tanzania, it is essential for investors to evaluate Tanzanian commercial banks' performance from macro variables and bank-specific factors perspectives before making any investment decision. The study also recommends that banks to maintain the leverage at optimal level for sustainable dividend payment. Moreover, investors are advised to invest in low or optimal leverage banks for assurance of dividend. Finally, the paper calls for policy makers to facilitate a freely stock market in the country in order to enhance growth of more commercial banks in the country.

The present paper has concentrated exclusively on Tanzanian regulated commercial banks with a sample size of six banks only. For a better reflection on the determinants of dividend of commercial banks in Tanzania, upcoming researches may want to take into account, other banks by increasing the sample size. Besides, this paper has solely used secondary data to derive its findings and conclusion. Therefore, the use of qualitative techniques for instance, interview and questionnaires are likely to provide wealthier data and thus robust results on factors affecting the dividend pay-outs of firms. Differently, an amalgamation of both quantitative and qualitative approaches may bring about more inclusive results. Last but not least, future researchers may want to include firmspecific variables such as investment opportunities, growth, risk, and age with added macro variables to determine the impact of both internal and external variables on the dividend policy of Tanzania commercial banks. In spite of its limitations, the present paper significantly adds to the available literature on dividend pay-out and the important aspects of dividend policy determinants of commercial banks in Tanzania.

\section{References}

Agyei, S. K., \& Marfo-Yiadom, E. (2011). Dividend policy and bank performance in Ghana. International Journal of Economics and Finance, 3(4), 202-207.

Ahmad, L., Iftikhar, Y., Ejaz, S., Baig, W., Nadeem, K., \& Shahid, R. (2019). Dividend Policy and Share Price volatility: Evidence From Pakistan Stock Exchange of Listed Commercial Banks. Issues in Economics and Business, 5(1), 35-44.

Al-Najjar, B., \& Kilincarslan, E. (2018). Revisiting firm-specific determinants of dividend policy: evidence from 
Turkey. Economic issues, 23(1).

Al - Malkawi, H. A. N. (2007). Determinants of corporate dividend policy in Jordan: an application of the Tobit model. Journal of Economic and Administrative Sciences.

Al Shabibi, B. K., \& Ramesh, G. (2011). An empirical study on the determinants of dividend policy in the UK. International Research Journal of Finance and Economics, 80(12), 105-124.

Alzomaia, T. S., \& Al-Khadhiri, A. (2013). Determination of dividend policy: The evidence from Saudi Arabia. International Journal of Business and Social Science, 4(1).

Amollo, K. O. (2016). The effects of dividend policy on firm value for commercial banks in Kenya University Of Nairobi].

Anil, K., \& Kapoor, S. (2008). Determinants of dividend payout ratios-a study of Indian information technology sector. International Research Journal of Finance and Economics, 15(1), 63-71.

Attah-Botchwey, E. (2014). The impact of dividend payment on share price of some selected listed companies on the Ghana Stock Exchange. International Journal of Humanities and Social Science, 4(9), 179-190.

Awad, B. (2015). Determinants of dividend policy in Kuwait stock exchange. International journal of business and management review, 3(7), 72-78.

Baker, H. K., \& Powell, G. E. (2000). Determinants of corporate dividend policy: a survey of NYSE firms. Financial Practice and education, 10, 29-40.

Baker, H. K., Powell, G. E., \& Veit, E. T. (2002). Revisiting the dividend puzzle: Do all of the pieces now fit? Review of Financial Economics, 11(4), 241-261.

Banerjee, S., Gatchev, V., \& Spindt, P. (2002). To pay or not to pay? The dividend dilemma of the liquid firm. $A B$ Freeman School of Business Working Paper, Los Angeles: Tulane University. Bebczuk, 1415-1431.

Bank of Tanzania (2019). Annual Data: www.go.tz.

Baskin, J., \& Miranti Jr, P. (1997). History of Corporate Finance [w:] Cambridge University Press, 263-270. DOI: http://dx. doi. org/10.1017/CBO9780511665219.

Charitou, A. (1999). The impact of losses and cash flows on dividends: empirical evidence for Japan. Available at SSRN 252063.

Dada, F. B., Malomo, E., \& Ojediran, S. (2015). Critical evaluation of the determinants of dividend policy of banking sector in Nigeria. International Journal of Economics Commerce and Management, 3(2), 1-11.

Daniels, K., Shin, T. S., \& Lee, C. F. (1997). The information content of dividend hypothesis: A permanent income approach. International review of economics \& finance, $6(1), 77-86$.

Denis, D. J., \& Osobov, I. (2008). Why do firms pay dividends? International evidence on the determinants of dividend policy. Journal of financial economics, 89(1), 62-82.

Easterbrook, F. H. (1984). Two agency-cost explanations of dividends. The American economic review, 74(4), 650-659.

Gill, A., Biger, N., \& Tibrewala, R. (2010). Determinants of dividend payout ratios: evidence from United States. The Open Business Journal, 3(1).

Gordon, M. J. (1959). Dividends, earnings, and stock prices. The review of economics and statistics, 99-105.

Gordon, M. J. (1962). The savings investment and valuation of a corporation. The Review of Economics and Statistics, 37-51.

Gordon, M. J., \& Shapiro, E. (1956). Capital equipment analysis: the required rate of profit. Management science, $3(1), 102-110$.

Gwahula, R., \& Mnyavanu, W. (2018). Determinants of dividend payout of commercial banks listed at dar es salaam stock exchange (DSE). Account and Financial Management Journal, 3(06), 1571-1580.

Hashemi, S. A., \& KASHANI, Z. F. (2012). The impact of financial leverage, operating cash flow and size of company on the dividend policy (case study of Iran).

Hausman, J. A. (1978). Specification tests in econometrics. Econometrica: Journal of the econometric society, 1251-1271.

Huda, F., \& Farah, T. (2011). Determinants of dividend decision: A focus on banking sector in Bangladesh. International Research Journal of Finance and Economics, 77(1), 33-46.

Pesaran, M. H., \& Shin, Y. (2003). Testing for unit roots in heterogeneous panels. Journal of econometrics, 115(1), 53-74.

Imran, K. (2011). Determinants of dividend payout policy: A case of Pakistan engineering sector. The Romanian Economic Journal, 41(14), 47-59.

Inyiama, E., Okwo, M., \& Inyiama, O. (2015). Dividend Payout Policy Determinants of Selected Listed Brewery Firms in Nigeria: A Meta-Analysis (2000-2013). European Journal of Business, Economics and Accountancy, $3(3), 101-118$.

Jabbouri, I. (2016). Determinants of corporate dividend policy in emerging markets: Evidence from MENA stock markets. Research in International Business and Finance, 37, 283-298.

Jensen, M. C. (1986). Agency costs of free cash flow, corporate finance, and takeovers. The American economic 
review, 76(2), 323-329.

Jensen, M. C., \& Meckling, W. H. (1976). Theory of the firm: Managerial behavior, agency costs and ownership structure. Journal of financial economics, 3(4), 305-360.

Khan, F. A., \& Ahmad, N. (2017). Determinants of dividend payout: An empirical study of pharmaceutical companies of Pakistan Stock Exchange (PSX). Journal of Financial Studies \& Research, 2017, 1-16.

Levin, A., Lin, C.-F., \& Chu, C.-S. J. (2002). Unit root tests in panel data: asymptotic and finite-sample properties. Journal of econometrics, 108(1), 1-24.

Lintner, J. (1956). Distribution of incomes of corporations among dividends, retained earnings, and taxes. The American economic review, 46(2), 97-113.

Lintner, J. (1962). Dividends Leverage, Stock Prices, and the Supply of Capital of Corporations. Review of Economics and Statistics, Vol. 44, No. 3, pp. 243-269, DOI: 10.2307/1926397.

Maladjian, C., \& Khoury, R. E. (2014). Determinants of the dividend policy: an empirical study on the Lebanese listed banks. International Journal of Economics and Finance, 6(4), 240-256.

Masum, A. (2014). Dividend policy and its impact on stock price-A study on commercial banks listed in Dhaka stock exchange. Global disclosure of Economics and Business, 3(1).

Mehta, A. (2012). An empirical analysis of determinants of dividend policy-evidence from the UAE companies. Global review of accounting and finance, 3(1), 18-31.

Miller, M., Modigliani, F., (1958). The Cost of Capital, Corporate Finance and the Theory of Investment. American Economic Review, 48, 261- 297

Miller, M. H., \& Modigliani, F. (1961). Dividend policy, growth, and the valuation of shares. the Journal of Business, 34(4), 411-433.

Mitiku, E. (2015). Determinants of Dividend payout: An Empirical Study in Ethiopian Private Banks.

Namachanja, L. (2016). Effects of Dividend Policy on Financial Performance of Listed Commercial Banks in Kenya University Of Nairobi].

Ngole, S. (2015). Dividend policy determinants: evidence from the Dar es Salaam Stock Exchange listed firms. African Journal of Finance and Management, 24(1-2), 51-64.

Nuhu, E. (2014). Revisiting the determinants of dividend payout ratios in Ghana. International Journal of Business and Social Science, 5(8).

Pandy, I. (2001). Corporate dividend policy and behavior the Malaysian experience.

Pattiruhu, J. R., \& PAAIS, M. (2020). Effect of liquidity, profitability, leverage, and firm size on dividend policy. The Journal of Asian Finance, Economics, and Business, 7(10), 35-42.

Pruitt, S. W., \& Gitman, L. J. (1991). The interactions between the investment, financing, and dividend decisions of major US firms. Financial review, 26(3), 409-430.

Ramli, N. M. (2010). Ownership structure and dividend policy: Evidence from Malaysian companies. International Review of Business Research Papers, 6(1), 170-180.

Raphael \& Mnyavanu, W. (2018). Dividend payout of commercial banks Account and Financial Management Journal

Rozeff, M. S. (1982). Growth, beta and agency costs as determinants of dividend payout ratios. Journal offinancial Research, 5(3), 249-259.

Salin, A., \& Rahman, R. A. (2010). Disclosure of board committees by Malaysian public listed companies. International Conference on Economics, Business and Management,

Sim, L. W. (2011). A study on leading determinants of dividend policy in Malaysia listed companies for food industry under consumer product sector.

URT. (2016). National Five years development Plan 2016/17 - 2020/21. Dar Es Salaam: URT

Utami, S. R., \& Inanga, E. L. (2011). Agency costs of free cash flow, dividend policy, and leverage of firms in Indonesia. European Journal of Economics, Finance and Administrative Sciences, 33(6), 7-24.

WorldBank. (2021). Raising the Bar-Achieving Tanzania's Development Vision. The World Bank Group-East Africa Region: World Bank Group

Yusof, Y., \& Ismail, S. (2016). Determinants of dividend policy of public listed companies in Malaysia. Review of International Business and Strategy.

Zameer, H., Rasool, S., Iqbal, S., \& Arshad, U. (2013). Determinants of dividend policy: A case of banking sector in Pakistan. Middle-East Journal of Scientific Research, 18(3), 410-424. 